\title{
Vowel Elision in Ikhin, an Edoid Language in South-south Nigeria
}

\author{
Opoola Bolanle T. \\ Department of Linguistics and Languages, Federal University, Oye-Ekiti, Ekiti State, Nigeria \\ Olaide Oladimeji \\ Department of Linguistics and Languages, Federal University, Oye-Ekiti, Ekiti State, Nigeria
}

\begin{abstract}
In this paper, attention is on the basic factors that come into force in determining whether or not vowel will elide and which of the $V_{1}$ and $V_{2}$ in a sequence should disappear in any environment. This paper also examines the phonological, morphological and syntactic reasons behind vowel elision as a syllable structure process in Ikhin language. As in the case of related African languages that have been previously described by various scholars, this paper presents how vowel elision works in Ikhin and the problems arising from its analysis. In this study, the focus is on the explanation and analysis of factors such as boundary, morpheme structure and vowel quality which actually determine whether or not elision should take place in Ikhin. Apart from factors such as vowel quality and boundary, one other factor with respect to elision or glide formation is the syllable structure of the verbs and nouns in Ikhin. Ikhin nouns are either disyllabic i.e. $V(C) V$ or trisyllabic, etc. It is argued that the operation of vowel elision is blocked in disyllabic nouns as /i/, /o/ and /u/ form glides when either of them occurs as $V_{1}$ whereas vowel elision rather than glide formation takes place in trisyllabic nouns. The study concludes based on data not previously discussed in the language that elision is driven by syllable-based and syntactic-based analyses and that a major strategy of discouraging vowel cluster in Ikhin is vowel elision because the syllable structure of the language prohibits cluster of vowels within word or across word boundary.
\end{abstract}

Index Terms — vowel elision, Ikhin language, boundary, morpheme structure, vowel quality

\section{INTRODUCTION}

Ikhin is one of the languages spoken in the Southern Nigeria. It belongs to Edoid language family. According Oladimeji (2013), it is a daughter language that belongs to the North-Central group of Edoid languages that was formerly known as Eastern Kwa. Categorically, Oladimeji (2010) states that the Ikhin language is spoken at Ikhin in Owan East Local Government Area of Edo State. For Blench (1989), the Eastern Kwa languages are recently classified as Benue-Congo (BC) and they form putative West Benue-Congo (WBC). However, the Edoid languages are majorly grouped into four. For Lewis (2013:160), they are North Central (NC), Northwestern (NW), Southwestern (SW) and Delta (D). Additionally, Elugbe (1989) recorded that the Edoid languages spread from the eastern Niger Delta in the Rivers and Bayelsa States through Delta State and Edo State into parts of Ondo and Kogi States (http://www.ling.mq.edu.au). This work is the first systematic exposition of the grammatical conditions for vowel elision in Ikhin language

\section{Methodology}

This study adopted an analytical and descriptive research design and on that, the data used for the study were gotten from seven selected native speakers in Ikhin town. The data were also collected from the Ibadan 1000 wordlist of the Summer Institute of Linguistics, and finally, from the University of Ibadan 400 wordlist. More so, the information used for the study was collected from traditional stories, conversations, descriptive statements and isolated, unelicited utterances (Oladimeji, 2013). The data were analysed using the speech filing system of the computerised speech laboratory.

\section{RELATED WORKS}

In a number of studies on Edoid languages, there has not been any reference to vowel elision in Ikhin. The only linguistic study on this language before now was done by Folarin (1982). It dwells mainly on the phonetics of the language.

\section{THEORETICAL FRAMEWORK}

The adopted theoretical framework of the study is Goldsmith's Autosegmental Theory (1976a) which is in prolongation to the traditional work of generative phonology that is in Chomsky and Halle's study in Sound Pattern of 
English (1968). Also, this theory was used in analysing and presenting the data used for the study. In generative phonology, a complete set of features was proposed and principles for writing phonological representation were also proposed. However, phonological representation was still linear in the sense that it was a single line of representation.

From the information above, the more parallel tiers of phonological segments were discovered in the work of John Goldsmith (1990) building on the work of Wil Leben Williams. For him, each tier of the phonological segments is made up of a string of segments although, the tiers for each segment are different due to their inherent features. Therefore, tonal features are represented on a separate tier independent of segmental tier, thus making tone autonomous in the sense that vowels can be deleted but the tone will retain its own tier of phonological segment and moves to a syllable that is adjacent to it in order to be in comformity with the maximal association in phonology.

Example:

1

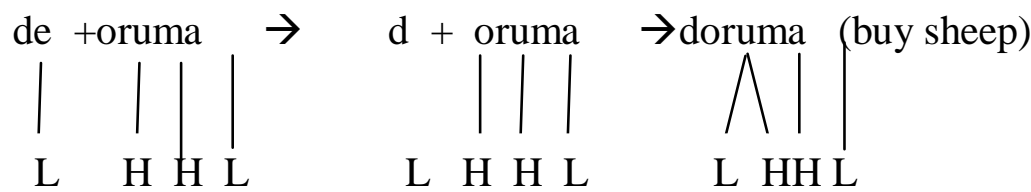

The most fundamental characteristic of autosegmental theory is that phonological representation is non-linear, that is, that a phonological representation is composed, not of a single sequence of entities but of several parallel sequences of entities arranged in two or more tiers, each of which is said to be independent of the others (Aziza 1997). Hierarchical model of this theory is used in presenting the data.

\section{VOWEL ELISION}

Vowel elision is a common phonological process in African languages in general and Edoid languages in particular. Vowel elision is found most commonly in kwa languages and that in such languages the syllable structure of verbs and nouns makes it possible for vowel sequences to occur across morpheme boundaries. (Welmers1973). In Ikhin and in such other Edoid languages like Urhobo (Aziza, 1997), Emai (Egbokhare, 1990) etc any of the vowel $\left(\mathrm{V}_{1}\right.$ or $\left.\mathrm{V}_{2}\right)$ can elide at boundary depending on construction type. However, in Ngwo (Njwe, 2005), a western Grass field Bantu language, spoken in the North West province of Cameroon, when two morphemes or words are juxtaposed only the $\mathrm{V}_{2}$ elides. This $\mathrm{V}_{2}$ is actually the noun class prefix vowel of the second word.

Potential vowel cluster in Ikhin may be avoided by dropping one of the vowels when two morphemes or words, one of which ends in a vowel and the other which begins with a vowel are combined. This is also referred to as boundary deletion.

Here, the aim is to layout basic factors that come into force in determining whether or not vowel will elide and which of the $\mathrm{V}_{1}$ and $\mathrm{V}_{2}$ in a sequence should disappear in any environment and to explain the phonological, morphological or syntactic reasons behind such a process. We begin by showing how vowel elision works in Ikhin and the problems arising from its analysis, also by explaining factors such as boundary, morpheme structure and vowel quality which actually determine whether or not elision should take place. An understanding of the following situations would go a long way in assisting us to appreciate the various explanations later provided as solutions to the problems of vowel elision in Ikhin.

i) $\quad V_{1}+V_{2}$ sequence, the $V_{1}$ is sometimes elided

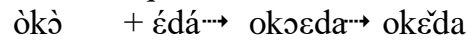

$$
\begin{aligned}
& \begin{array}{lll}
\mathrm{V}_{1} & \mathrm{~V}_{2} & \mathrm{~V}_{1} \mathrm{~V}_{2}
\end{array} \\
& \text { 'motor' 'river' 'canoe or boat' }
\end{aligned}
$$

ii) $\quad \mathrm{V}_{2}$ may be elided in $\mathrm{V}_{1}+\mathrm{V}_{2}$ sequence

$$
\begin{aligned}
& \text { Éwè+ònà } \rightarrow \text { Éwè ona } \rightarrow \quad \text { Éwènằ } \\
& \begin{array}{lll}
\mathrm{V}_{1} & \mathrm{~V}_{2} & \mathrm{~V}_{1} \mathrm{~V}_{2}
\end{array} \\
& \text { 'goat' 'this' 'this goat' }
\end{aligned}
$$

iii) Sometimes, no elision of either $\mathrm{V}_{1}$ or $\mathrm{V}_{2}$ when occurring in sequence across morpheme boundary.

òmóhènì +éhù + ódè $\rightarrow \rightarrow$ òmóhènì niéhù ód $\varepsilon \rightarrow$ òmóhènì éhùódè

$$
\mathrm{V}_{1} \mathrm{~V}_{2}
$$

'man die yesterday' 'The man died yesterday'

d) When high vowels /i/ and / $\mathrm{u} /$ occur at $\mathrm{V}_{1}$ position and are followed by an unidentical vowel across morpheme boundary, glide formation rather than vowel elision takes place (this situation also applies to /o/)
iv) $\mathrm{fi}+$ ákà $\cdots \rightarrow \mathrm{fj}+$ ăkà $\quad \rightarrow \quad$ fjăkà
$\begin{array}{lll}\mathrm{V}_{1} & \mathrm{~V}_{2} & \mathrm{CV}_{2}\end{array}$
'throw' 'basket' 'throw a basket'
v) rò + j̀kpòsò $\cdots \rightarrow$ rw+ okposo $\rightarrow$ rwòkpòsò
$\begin{array}{lll}\mathrm{V}_{1} & \mathrm{~V}_{2} & \mathrm{CV}_{2}\end{array}$ 


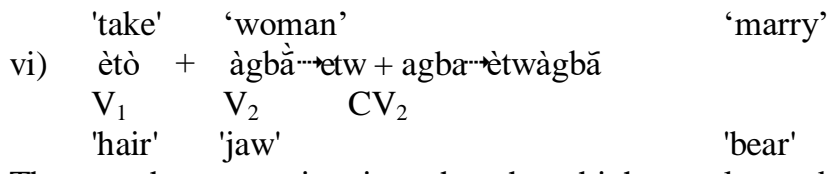

There are however, situation when these high vowels are deleted in this same environment

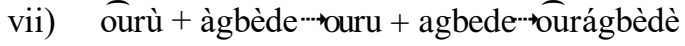

$\begin{array}{lll}\mathrm{V}_{1} \mathrm{~V}_{2} & \mathrm{~V}_{1} \mathrm{~V}_{2}\end{array}$

'thread' 'needle'

'needle's thread'

f) The final vowel of a verb may be deleted in a construction and retained in another construction despite the fact that it is followed by the same vowel across word boundary.

viii) $\mathrm{m} \varepsilon \dot{\varepsilon}+\mathrm{d} \varepsilon+$ òpìa $\cdots \mathrm{m} \varepsilon \dot{\varepsilon}+\mathrm{d} \varepsilon+$ òpìa $\quad \rightarrow \quad$ mé dòpjà $\mathrm{V}_{1} \mathrm{~V}_{2} \quad \mathrm{~V}_{1} \mathrm{~V}_{2}$

I buy matchet

ix) $\quad \mathrm{m} \varepsilon \dot{\varepsilon}+\mathrm{d} \varepsilon+j \quad \ldots$

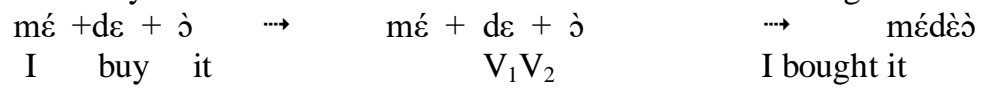

Besides, in a verb-noun object sequence, the final vowel of the verb sometimes stays and at other times it goes even when it is followed by the same object. This is more so when the main verb is preceded by the auxiliary. "Whenever there is a seeming contradiction in the operation of two rules, it is almost certain that the language will carefully delineate the kind of area in which the one or the other can operate" (Oyebade, 1998).

Though, in Ikliin, vowel elision does not take place at boundary between syntactic categories such as auxiliary and the main verb, noun and a following verb, verb and adverb, noun and article, however, when these items occur in an adjacent position to other lexical items e.g verb-noun, verb-numeral, verb-qualifier elision takes place.

All that has been said so far is to generalise by describing the mode of vowel elision in Ikhin. Any factor or reason that may have been advanced for being responsible for vowel elision in this language must also account for why elision takes place in certain environment but is blocked in another environment, not only that it must also account for the reason why it is $\mathrm{V}_{1}$ that elides in one environment and $\mathrm{V}_{2}$ in another environment.

It is at this level that explanations on phonological and syntactic factors in addition to vowel quality and morpheme structure conditions are offered. Apart from factors such as vowel quality and boundary, one other factor with respect to elision or glide formation is syllable structure of the verbs and nouns in Ikhin. Ikhin nouns are either disyllabic i.e. $\mathrm{V}(\mathrm{C}) \mathrm{V}$ or trisyllabic etc. The operation of vowel elision is blocked in disyllabic nouns as /i/, /o/and / $\mathrm{u} /$ form glides when either of them occurs as $\mathrm{V}_{1}$ whereas vowel elision rather than glide formation takes place in trisyllabic nouns.

On the other hand, the minimal syllable structure of verbs in Ikhin is (C)V. A verb can either be monosyllabic or disyllabic, a situation that is true of most Edoid languages. Vowel elision takes place in disyllabic verbs, while monosyllabic verb laving /i/, /u/, /o/ as $\mathrm{V}_{1}$, has its $\mathrm{V}_{1}$ turned to glide when it is followed by a stronger $\mathrm{V}_{2}$

The strength hierarchy presupposes mat the pronoun and verb categories would lose their vowels when in near adjacency to qualifier and noun categories. Having understood the foundation for the application or otherwise of vowel elision in Ikhin, we will now provide construction types where elision takes place and its effects on tones and nasality.

\section{A. $V_{1}$ Elision}

\section{Compound words}

Vowel elision takes place in the formation of compound words. When two words are juxtaposed to form a compound word, the final vowel of the first word is lost or dropped, provided the following word begins with another vowel.

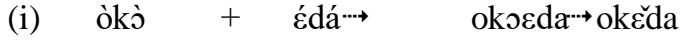

(ii) omoòkpòsò

$\begin{array}{lll}\mathrm{V}_{1} & \mathrm{~V}_{2} & \mathrm{~V}_{1} \mathrm{~V}_{2}\end{array}$

'motor' 'river' 'boat (canoe)'

(ii) omoòkpòsò $\quad \rightarrow \quad \rightarrow \quad$ òmò òkpòsò $\quad \rightarrow \quad \rightarrow \quad$ òmòkpòsò

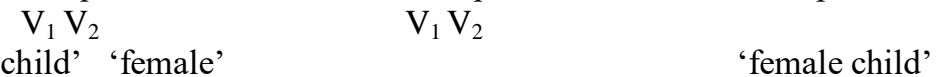

2. Transitive verb - object

So, $V_{1}$ elision occurs at the boundary between a transitive verb and its object.

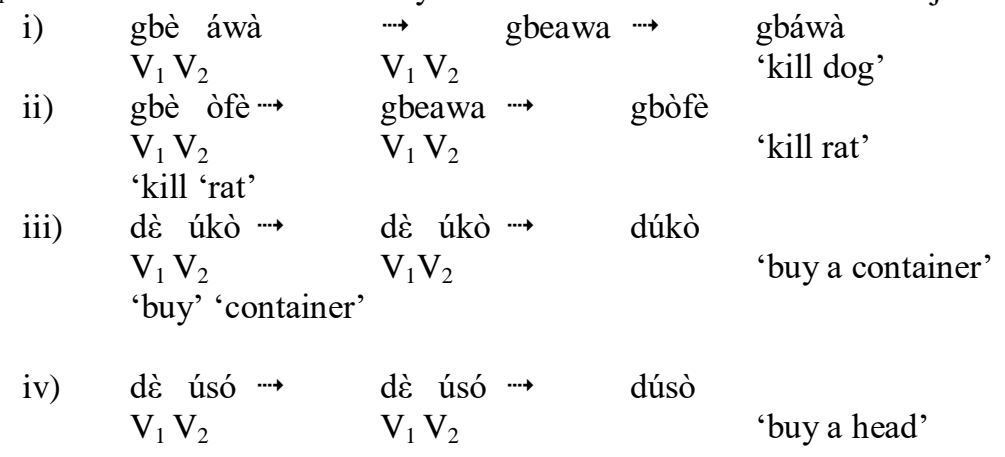




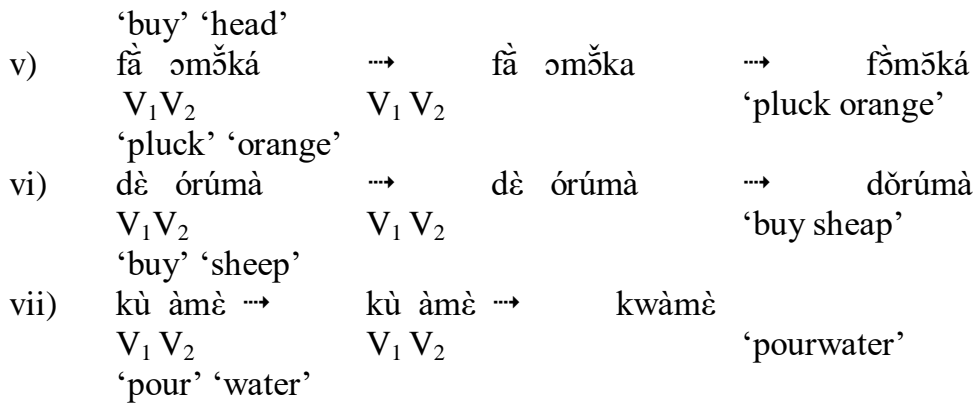

\section{Numeral construction}

$\mathrm{V}_{1}$ elision has equally been observed in the numeral constructions as shown below:
i) ìgbè j̀kpá
$\mathrm{V}_{1} \mathrm{~V}_{2}$
$\overrightarrow{\mathrm{V}_{1}} \mathrm{~V}_{2} \quad$ igbeskpa 'eleven'
'ten' 'one'
ii) ìgbè éhà $\cdots$
$\mathrm{V}_{1} \mathrm{~V}_{2}$ 'ten' 'three'
igbeeha $\rightarrow \quad$ ìgbèhà
$\mathrm{V}_{1} \mathrm{~V}_{2} \quad$ 'thirteen'

\section{Article - Noun Construction}

In the noun phrase construction involving article, the word order in this language is for the article to come before the noun it modifies. In this construction, the stem vowel of the article which is $\mathrm{V}_{1}$ at word boundary is deleted as shown below:

\begin{tabular}{|c|c|c|c|}
\hline òlì óbò & $\rightarrow$ & oliobo & $\rightarrow \quad$ j̀lóbò \\
\hline $\begin{array}{l}\mathrm{V}_{1} \mathrm{~V}_{2} \\
\text { 'the' 'doctor' }\end{array}$ & $\mathrm{V}_{1} \mathrm{~V}_{2}$ & & 'the doctor' \\
\hline j̀lì j́kpòsò & $\cdots$ & oliokposo & ólòkpòsò \\
\hline $\begin{array}{l}\mathrm{V}_{1} \mathrm{~V}_{2} \\
\text { 'the' 'woman' }\end{array}$ & $\mathrm{V}_{1} \mathrm{~V}_{2}$ & & 'the woman'' \\
\hline j̀lì Éwè & $\rightarrow \rightarrow$ & olicwe & $\rightarrow \quad$ ólèwè \\
\hline $\begin{array}{l}V_{1} V_{2} \\
\text { 'the' 'goat' }\end{array}$ & $\mathrm{V}_{1} \mathrm{~V}_{2}$ & & 'the goat' \\
\hline èlì òì & $\rightarrow$ & elioi & $\rightarrow \rightarrow \quad$ èlòì \\
\hline $\begin{array}{l}\mathrm{V}_{1} \mathrm{~V}_{2} \\
\text { 'the' 'thief' }\end{array}$ & $\mathrm{V}_{1} \mathrm{~V}_{2}$ & & 'the thieves' \\
\hline èlì ódì & $\cdots$ & eliodi & $\rightarrow \quad$ èlódì \\
\hline $\mathrm{V}_{1} \mathrm{~V}_{2}$ & $\mathrm{~V}_{1} \mathrm{~V}_{2}$ & & 'the walls' \\
\hline
\end{tabular}

Under normal condition [i] does not delete but it deletes here because it belongs to a modifier (article).

\section{B. $V_{2}$ Elision}

\section{Noun - Demonstrative Construction}

In Ikhin and perhaps in most African languages, the word-order in noun phrase is for the demonstratives to follow the nouns they qualify. In this case, the prefix vowel of this demonstrative $\left(\mathrm{V}_{2}\right)$ is dropped when it is in an adjacent position to the $\mathrm{V}_{1}$ of a head noun e.g. the vowel of the modifier is dropped because the demonstrative is a modifier. It is a concord marker prefix not a class prefix.

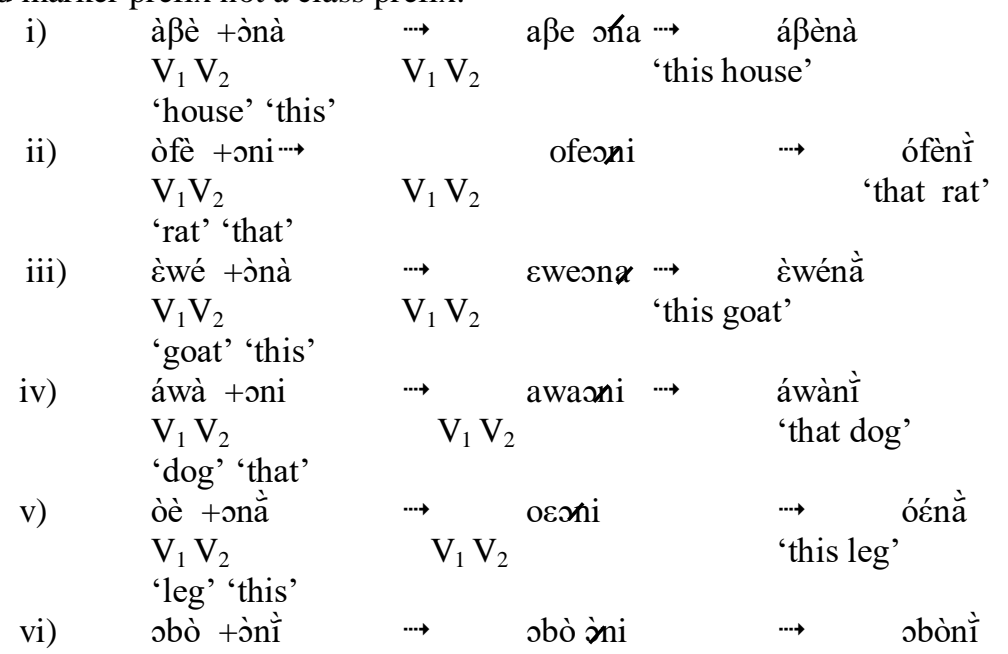




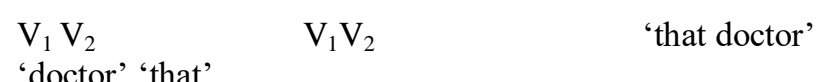

\section{Noun Associative Construction}

In the noun-associative constructions, however, the associative marker /iš̀/ which intervenes between the two nominals has its two vowels (prefix and suffix) deleted. In this elision process, the prefix vowel /i/ is $\mathrm{V}_{2}$ elision while the suffix vowel $/ \varepsilon /$ is $\mathrm{Vi}$ elision.

Examples:

i)

ii)

iii)

\begin{tabular}{|c|c|c|c|c|}
\hline ćkpà ísè obà & $\rightarrow$ & ع́kpà ísè obà & $\rightarrow$ & ćkpàsj̀bà \\
\hline $\begin{array}{l}\mathrm{V}_{1} \mathrm{~V}_{2} \mathrm{~V}_{1} \mathrm{~V}_{2} \\
\text { 'bag' 'am' 'king', }\end{array}$ & & $\mathrm{V}_{1} \mathrm{~V}_{2} \mathrm{~V}_{1} \mathrm{~V}_{2}$ & & 'king's bag' \\
\hline $\begin{array}{l}\text { áwà ísè òhùà } \\
V_{1} V_{2} V_{1} V_{2}\end{array}$ & $\cdots$ & $\begin{array}{l}\text { áwà ísè òhùà } \\
V_{1} V_{2} V_{1} V_{2}\end{array}$ & $\cdots$ & $\begin{array}{l}\text { áwàsohwà } \\
\text { 'hunter's dog' }\end{array}$ \\
\hline
\end{tabular}

'dog' 'am' 'hunter'

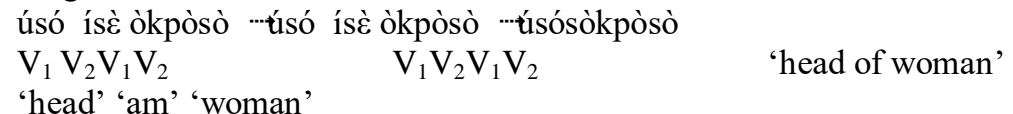

In the above examples, the associative marker /ise/ (V-CV) has its initial and final vowels dropped while the vowels of the nouns being fused together are retained. This is borne out of the fact that the marker is weaker in strength than the nouns and as such loses its vowels when in juxtaposition with the stronger constituents such as nouns. Though in fast speech, the whole associative marker may go.

However, this process does not occur as claimed earlier if $\mathrm{V}_{1}$ is a close vowel i.e. /i/ and / $\mathrm{u} /$ therefore, it is blocked by another process called glide formation. Also syntactic rules such as word order rule block vowel elision within primary constituents because such constituents have undergone verb movement as in the following examples:

i)

ii)

$\begin{array}{lccc}\mathrm{N} & \text { Aux } & \mathrm{V} & \mathrm{Adv} \\ \text { omb́hè } & \text { è } & \text { hu } & \text { ód ̀̀ } \\ \text { man } & \text { die } & \text { yesterday } & \\ \text { The man died yesterday } & \end{array}$

The man died yesterday

ìjằ xé lùmò ákùc̀

mother will travel tomorrow

iii)

$$
\text { The mother will travel tomorrow }
$$

obè ófè ódè

dog kill rat yesterday

The dog killed rat yesterday

The vowel elision processes discussed above affect the status of other segments such as tone and nasality. The reason for this is that all the affected vowels are tone bearing units while only a few of the affected vowels bear nasality. In autosegmental phonology, the features of the segments (vowels and consonants) and those of the tones are contained in separate tiers. The relation of tones to the vowels with which they are associated is simultaneous in time.

The sample derivations for autosegmental representation of vowel elision processes will also include the effects of these processes on tones. When vowels are deleted, their tones are automatically set afloat and later relinked by an association convention for tones which is a set of requirements on phonological representation to be linked to the other parts of the phonological structure.

According to Goldsmith (1976), the value of autosegmental analysis was explicit in the analysis of tone in African languages. He then maintains that there are phonological rules that apply independently to tonal and segmental levels during an autosegmental representation and finally states clearly that there are rules that delete a segment but can leave a tone that is associated with the segment unaffected (http://www.ling.mq.edu.au).

Examples from Ikhin

$$
\begin{aligned}
& \text { òkj̀ }+ \text { édà } \rightarrow \text { òkědà } \\
& \begin{array}{ll}
\mathrm{v}_{1} \mathrm{~V}_{2} & \mathrm{H} \mathrm{L} \text { 'boat' }
\end{array} \\
& \text { 'motor' 'river' }
\end{aligned}
$$

Rule 1: $\quad$ Delete $\mathrm{V}_{1}$, but do not delete its low tone

$$
\text { (ii) òk' }+ \text { ćdà }
$$

From the above example, one can actually understand and see the presence of an unattached low tone which, in other words, means a tone that is left after the vowel [0] has been deleted. Based on this, there is need to have a rule that will mandate unattached tones to be attached to the nearest vowel. In line with the following, it can be said that the tone on

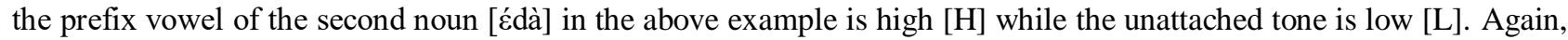
in combining the low tone and high tone, it brings about a low tone ensued by a high tone [L then $\mathrm{H}$ ]. In other words, it can be called a rising tone or contour tone. However, on the part of rule changes in an autosegmental representation where tones and segments appear on separate levels, phonologists are at work in this regard (http://www.ling.mq.edu.au). 
For example, the UR for ok̀̀ + ćdà would be

iii)
tonal tier

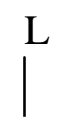
$\begin{array}{ll}\mathrm{H} & \mathrm{H} \\ & \end{array}$
L
CV tier<smiles>CC[V]</smiles>
$v_{1} \quad V_{1}$<smiles>CCCCC</smiles>
Segmental tieR ò
$\mathrm{k}$

From the above example, it can be seen that at the segmental level, there is a rule that postulates the deletion of the final vowel of the first word when it is succeeded by another vowel at word boundary (http://www.ling.mq.edu.au).

iv)

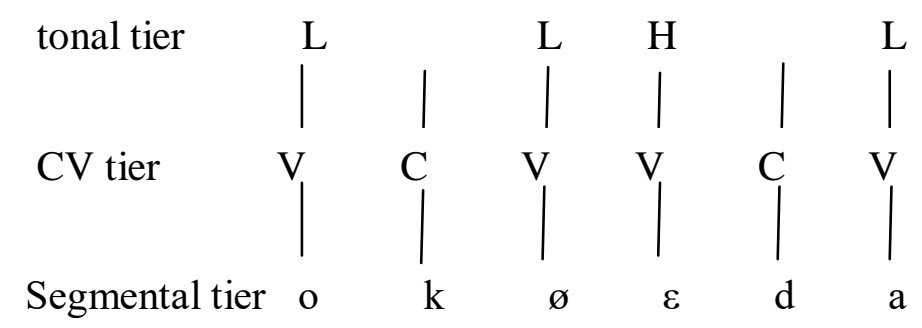

We now have a floating low tone which is attached to the nearest vowel.

(v)

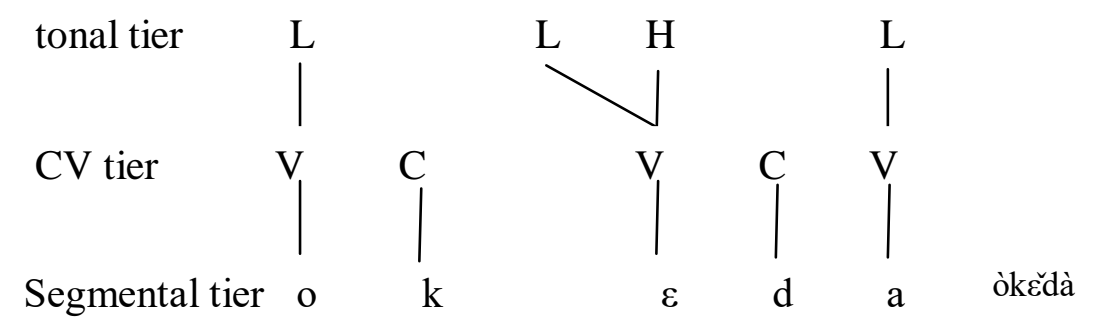

In other words, we have an $\mathrm{LH}$ (=rising) tone attached to vowel $[\varepsilon]$, that is $\mathrm{V}_{2}$ at word boundary.

Furthermore, these unattached (floating) tones result in various tonal modifications. When $\mathrm{V}_{1}$ which bears a high tone $[\mathrm{H}]$ elides and $\mathrm{V}_{2}$ which bears a low tone [L] remains, the high tone on the elided $\mathrm{V}_{1}$ is set afloat and later relinks. This relinking of high tone $[\mathrm{H}]$ results in the automatic delinking (and deletion) of low tone. This is so in verb-noun object and demonstrative constructions.

Examples:
i)

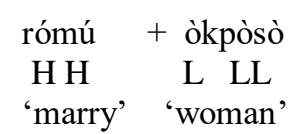
$\rightarrow \quad$ rómókpósò
ii) j̀kpá + onà
L H L L
'cock' 'this'
$\rightarrow \quad$ jòkpánà
'marry wife'
'this cock'

This can be illustrated with the following sample derivations:

iii)

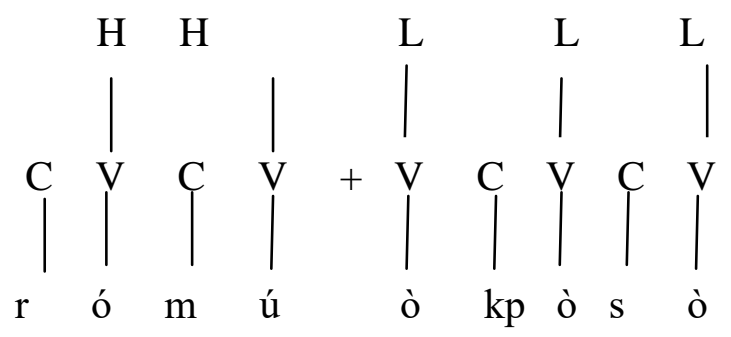

Underlying representation 
iv)

By vowel elision

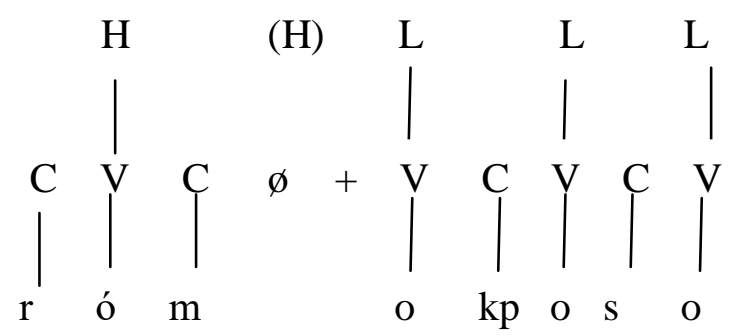

v)

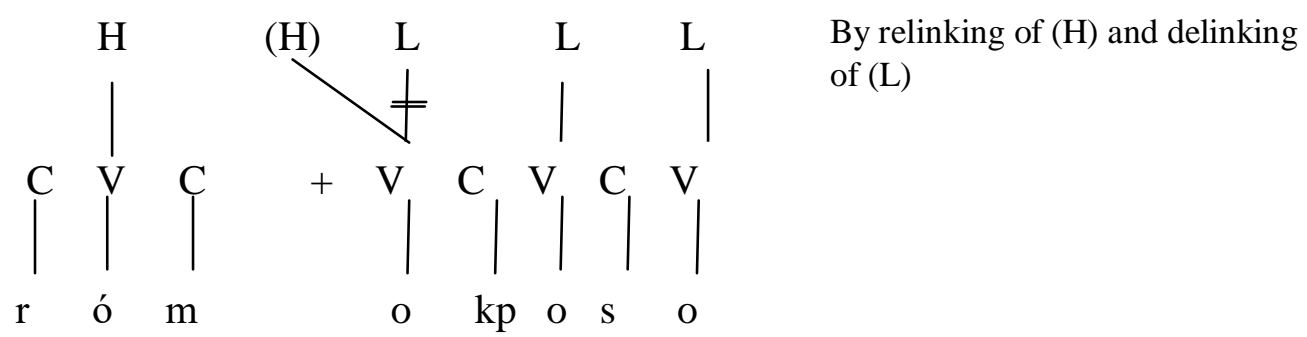

vi)

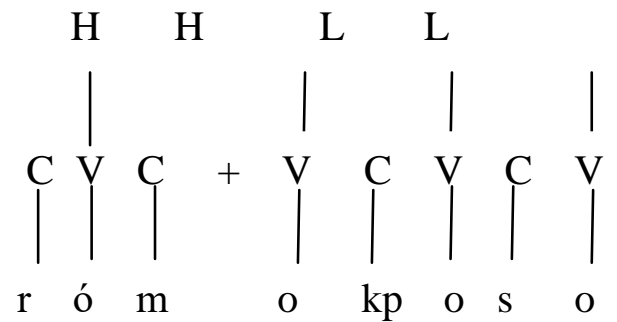

Surface representation (following deletion of L)

\section{[rómókpòsò] 'marry wife'}

i)

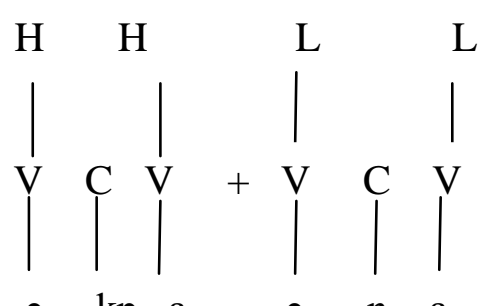

Underlying representations

ii)

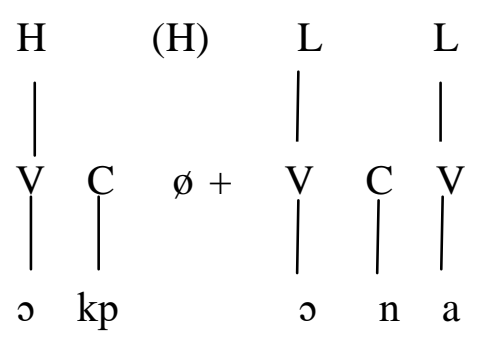

By vowel elision

iii)

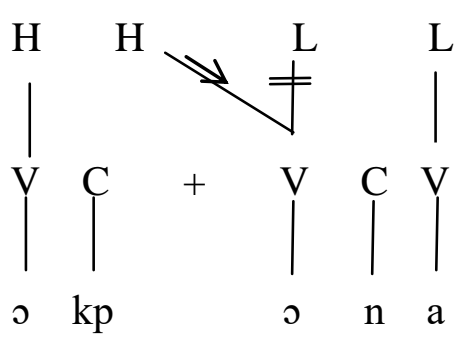

By relinking of $(\mathrm{H})$ and delinking of (L) 
iv)

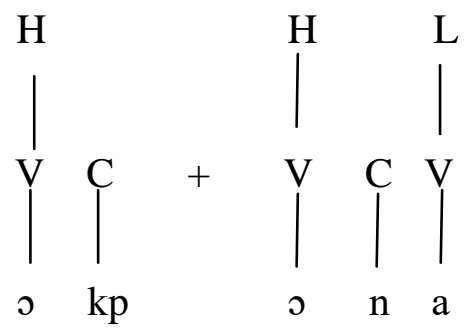

[òkpónằ] 'This cock'

When at boundaries in the formation of compound words, numeral constructions verb - noun objects, $V_{1}$ and $V_{2}$ bear identical tones, there is vacuous relinking (that is, redundant) thus, no tonal modification occurs.

Examples:

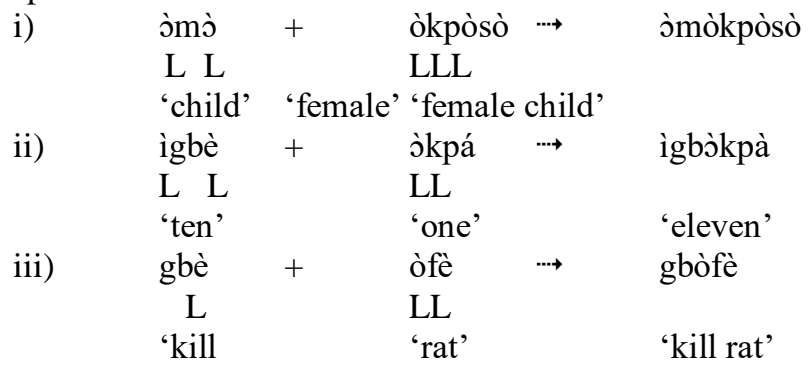

These are some sample derivations of the above:
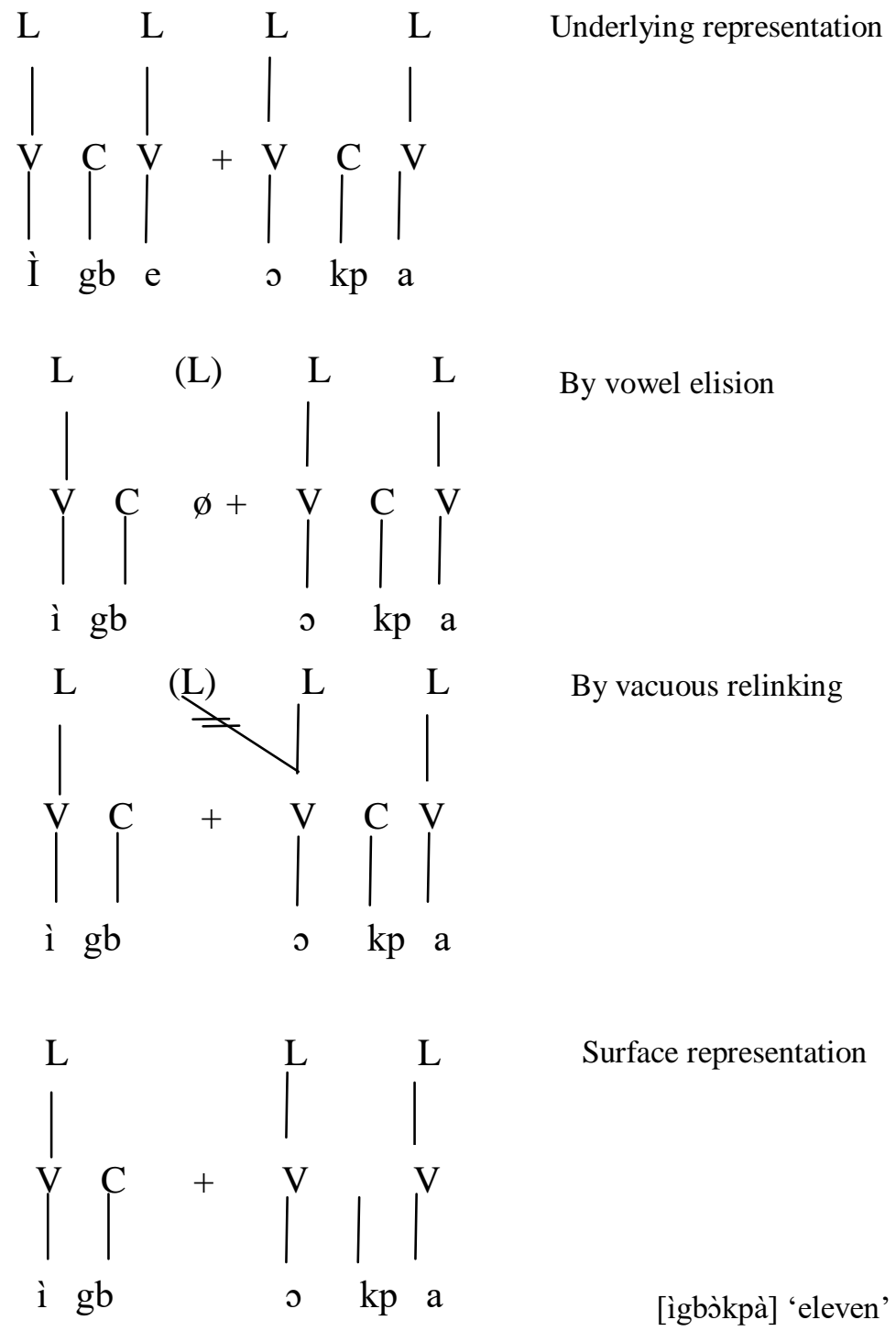


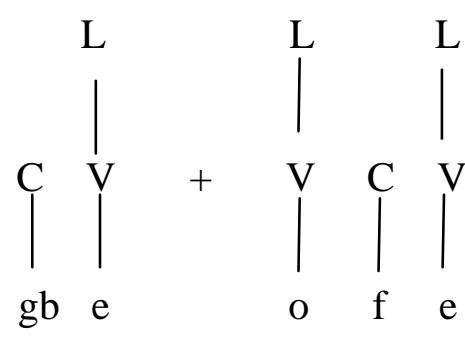

Underlying representation
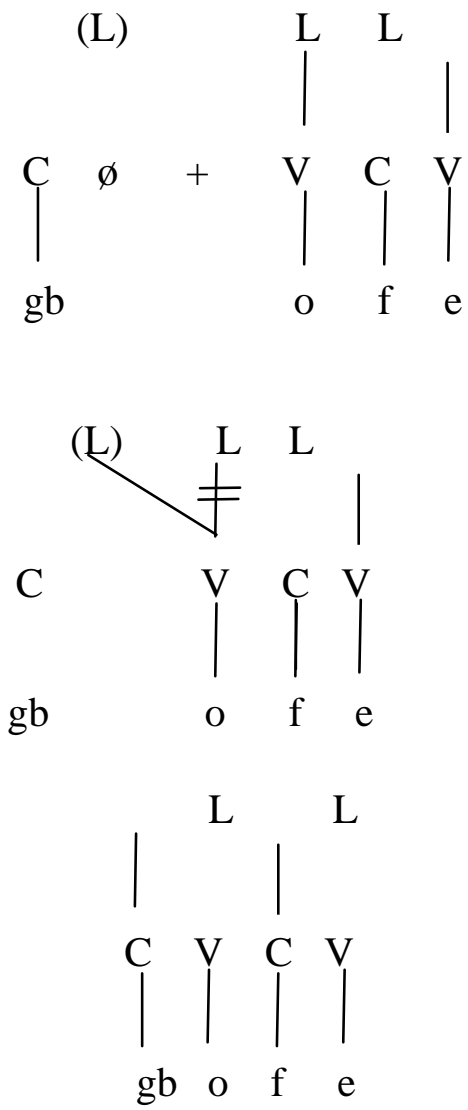

By vowel elision

By (L) vacuous delinking

Surface representation

[gbòfè] 'kill rat'

\section{CONCLUSION}

One of the common strategies for eliminating vowel clusters in most African languages is vowel elision. This paper has confirmed vowel elision as a syllable structure process in Ikhin. It was established that the syllable structure of verb and noun in Ikhin language makes it possible for vowel sequence to occur across morpheme boundaries. The study shows how vowel elision works in Ikhin and the problems arising from its analysis. In this paper, factors such as boundary, morpheme structure and vowel quality which actually determine whether or not elision should take place were explained. Vowel elision process and its effects on tone were presented through autosegmental representation confirming tone stability after the deletion of vowel on which it was grounded.

\section{REFERENCES}

[1] Aziza, R. (1997). "Urhobo Tone System”. Unpublished Ph.D. Thesis, University of Ibadan.

[2] Blench, R. (1989). New Benue - Congo. A Definition and Proposed Internal Classification. ArbeitsPapiere. 17: 115 - 147.

[3] Chomsky, N and Halle, M. (1968). The Sound Pattern of English. New York: Harper \& Row

[4] Egbokhare, F. (1985). "Vowel Elision in Emai’ Unpublished M.A Project, University of Ibadan

[5] Egbokhare, F. (1990). "A Phonology of Emai". Unpublished Ph.D Thesis, University of Ibadan.

[6] Elugbe, B. (1989). Edoid. In J.T. Bendor-Samuel (ed.). The Niger-Congo Languages, 291-304. New York: University Press of America.

[7] Folarin, Y. (1982). Aspects of the Phonetics and Phonology of Ikhin. An unpublished M.A. Dissertation, University of Ibadan.

[8] Goldsmith, J. (1976a). “Autosegmental Phonology”. Unpublished PhD. Thesis. Massachusetts Institute of Technology (MIT)

[9] Goldsmith, J. (1990). Autosegmental and Metrical Phonology. Oxford: Basil Blackwell.

[10] http://www.ling.mq.edu.au. 
[11] Kenstowicz, M. (1994). Phonology in Generative Grammar. Oxford, UK Blackwell.

[12] Kiparsky, F. (1968). “How abstract is Phonology?” Bloomington. Indiana: Indiana University Linguistics Club.

[13] Leben, W. (1973). The Role of Tone in Segmental Phonology. In L. Hyman (ed.) Consonant Types and Tones southern California: Occasional papers in Linguistic No. 1: 117 - 149.

[14] Lewis, A. A. (2013). North Edoid relations and roots. Doctoral dissertation, University of Ibadan.

[15] Njwe, A. (2005). “Tone Analysis of Ngwo in Cameroon”. Unpublished PhD Thesis, University of Ibadan.

[16] Oladimeji, O. (2010). A Phonology of Ikhin, an Edoid Language in South-South, Nigeria. Unpublished Ph.D Thesis, University of Ibadan.

[17] Oladimeji, O. (2013). The Tone System of Ikhin. Open Science Repository Language and Linguistics. www.open-sciencerepository.com.

[18] Ostendorp, M. (2005). Autosegmental Phonology. An Overview of some of the basic principles of Autosegmental Phonology. http:/en.wikipedia org./wiki:21:4:05.

[19] Oyebade, F. (1998). A Course in Phonology. Ijebu-Ode Sebiotimo Publication. Website of the Department of Linguistics, Macquarie University. http://www.ling.mq.edu.au.

[20] Welmers, W. (1973). African Language Structures. Los Angeles: University of California Press.

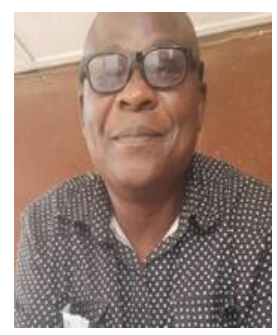

Tajudeen Bolanle Opoola was born in Oyo, Nigeria in 1959. He received his $\mathrm{PhD}$ degree in Linguistics from University of Calabar, Nigeria in 2001.

He is currently a Professor in the Department of Linguistics and Languages, Federal University, Oye-Ekiti, Nigeria. His research interests include Applied Linguistics and African languages.

Professor Opoola is a member of Linguistics Association of Nigeria and Patron, Association of Nigerian Authors, Oyo State branch, Nigeria.

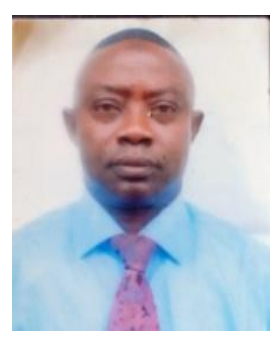

Olaide Abduwaheed Oladimeji was born in Ibadan, Nigeria 1969. He received his PhD degree in Linguistics from University of Ibadan in 2010.

He is a Lecturer 1 in the Department of Linguistics and Languages, Federal University, Oye-Ekiti, Nigeria. His research interests include Phonology and Syntax of African languages.

Dr. Oladimeji is member of Linguistics Association of Nigeria. 